\title{
Evaluation of esophageal injuries secondary to ingestion of unlabeled corrosive substances: pediatric case series
}

\author{
Gonul Kucuk, M.D. ; Gulnur Gollu, Assist. Prof. ; Ufuk Ates, M.D. ; Zeynep A. Cakmak, Prof. ; \\ Meltem Kologlu, Prof. ; Aydin Yagmurlu, Prof. $;$; Tanju Aktug, Prof. ; Huseyin Dindar, Prof. ${ }^{a}$ and \\ Ahmet M. Cakmak, Prof. ${ }^{a}$
}

\begin{abstract}
Esophageal or gastric injuries secondary to caustic substance ingestion is still an important issue in developing countries. Its clinical spectrum can vary from absence of mucosal injury to complications such as severe burns, strictures and perforation. Physical examination and first endoscopic evaluation are very important in the diagnosis. The objective of this study is to present 154 children who were undergone upper gastrointestinal endoscopy because of caustic substance ingestion including descaler, degreaser, unlabeled bleach, drain opener, surface cleaner, dishwasher rinse aid, hydrochloric acid. Sixty-nine children had positive oropharyngeal findings. Sixtythree children were found to have burns in the first endoscopic examination and forty of these burns were severe burn. In the follow-up, twenty children developed strictures that were undergone dilatation program. Fourteen children in the dilatation program had successful dilatation and intralesional steroid injection. However three children had undergone colonic interposition and three undergone laparoscopic gastroduodenostomy and gastrojejunostomy.
\end{abstract}

Key words: child, caustics, esophagus, eating, universal precautions.

http:/ /dx.doi.org/10.5546/aap.2017.eng.e85

To cite: Kukuc G, Gollu G, Ates U, et al. Evaluation of esophageal injuries secondary to ingestion of unlabeled corrosive substances: pediatric case series. Arch Argent Pediatr 2017;115(2):e85-e88.

\section{INTRODUCTION}

Corrosive substance ingestion occurs most commonly in children, especially those less than three years of age. ${ }^{1,2}$ Ingestions are primarily

a. Ankara University, School of Medicine, Department of Pediatric Surgery, Ankara, Turkey.

b. Ufuk University, School of Medicine, Department of Public Health, Ankara, Turkey.

E-mail address:

Gulnur Gollu, Assist. Prof.: drggollu@yahoo.com

Funding: None.

Conflict of interest: None.

Received: 5-25-2016

Accepted: 10-19-2016 accidental in this age group..$^{1,3}$ The possibility of injury varies depending on the physical characteristics, concentration and quantity of the substance ingested. ${ }^{1,4}$

Some of the corrosive substances ingested were found to be bought from small markets or from the street vendors, which are sold in coke or water bottles without a brand name. The importance of these unlabeled caustic substances is that ingredients are unknown, their concentration is unknown and they are usually odorless or colorless without an original bottle. Therefore, the aim of this study was to analyze the injuries following ingestion of caustic substances, emphasize the severity of unlabeled caustic substances and besides provide information about preventive measures in this issue.

\section{Cases}

The study was performed in Ankara University School of Medicine, Department of Pediatric Surgery in adherence to the Declaration of Helsinki. A written informed consent was signed by the legal guardians of each child. This is a retrospective study of 154 pediatric patients who were undergone upper gastrointestinal endoscopy (UGE) because of caustic substance ingestion from 2009 to 2015. The children under 18 years old and ingested caustic substance including descaler, degreaser, unlabeled bleach, drain opener, surface cleaner, dishwasher rinse aid, hydrochloric acid were included in the study. The children who ingested labeled bleach were excluded from the study since they were not accepted as caustic substance. ${ }^{5}$

Seventy-nine of the children were male and 75 were female. The age of children ranged from one month to 16 years and 106 of them were three years old or less.

Sixty-nine of the children had positive oropharyngeal physical examination ie. superficial mucosal hyperemia and edema. 154 children were undergone UGE because of caustic substance ingestion including descaler, degreaser, unlabeled bleach, drain opener, surface 
cleaner, dishwasher rinse aid, hydrochloric acid. There was no severe burn in 10 children who ingested unlabeled bleaches.

Two or more degree burns were evaluated as "severe burns" and sixty-three children were found to have burns in the first endoscopic examination and forty of these burns were regarded as "severe burn" (Table 1). ${ }^{6}$ Patients with "severe burn" received antibiotics, oral corticosteroids and $\mathrm{H}_{2}$-receptor blockers.

Seventy-five of the severe burns were found to be in degreaser or descaler ingested patients. Among 154 children, fifty children ingested degreaser or descaler and 14 of these ingested labeled, 29 don't know the brand name and seven ingested unlabeled degreaser/descaler. Degreasers/descalers cause injuries more than other caustic substances and injury is even more following unlabeled degreasers/descalers. Severe burn was detected in 50\% of labeled degreaser / descaler ingested patients, in $62 \%$ of unknown degreaser/descaler ingested patients and $71 \%$ of unlabeled degreaser/descaler ingested patients.

All of the patients who ingested caustic substance were required to have contrast studies three weeks after the ingestion. However only $49 \%(n=75)$ of the patients came to outpatient clinics with their results. Remaining patients discontinued their follow-up.

Twenty children developed strictures that were undergone dilatation program. Rest of the children who were in the follow-up had no stricture or swallowing problem. Fourteen children in the dilatation program had successful dilatation and intralesional steroid injection. However three children had undergone colonic interposition and three undergone laparoscopic gastroduodenostomy and gastrojejunostomy.

TABLE 1. Endoscopic classification of esophageal injuries

\begin{tabular}{ll}
\hline Classification & Depth of mucosal involvement \\
\hline Grade I & $\begin{array}{l}\text { Superficial mucosal hyperemia, edema, and } \\
\text { sloughing }\end{array}$ \\
Grade II & $\begin{array}{l}\text { Transmural involvement with exudates, } \\
\text { ulceration, and muscle involvement and } \\
\text { pseudomembrane formation }\end{array}$ \\
Grade III & $\begin{array}{l}\text { Eschcar formation, obliteration of lumen, } \\
\text { and deep ulceration }\end{array}$ \\
Grade IV & $\begin{array}{l}\text { Erosion through the esophagus into the } \\
\text { periesophageal tissue, mediastinum, pleural } \\
\text { or peritoneal cavities }\end{array}$ \\
\hline
\end{tabular}

\section{DISCUSSION}

A corrosive substance is one that will destroy and damage another surface or substance with which it comes into contact and has an ability to burn organic tissue by chemical action. Caustic substance ingestion by children is still an important public health issue, especially in developing countries because of unavailability of strict laws and obligations concerning household cleaning products. ${ }^{3}$ In Turkey, the studies have shown that caustic substance ingestion has become first in the list of poisonings recently. ${ }^{7}$ Sarioglu-Buke et al. and Temiz et al. stated that corrosive substance ingestion carries great risk of mortality and morbidity, decreases quality of life significantly, may lead to economic hardship due to medical costs, psychosocial problems including behavioral, educational and domestic problems and besides carries judicial issues. ${ }^{8,9}$ Primary goal should be the prevention of caustic substance burns by using preventive medicine studies instead of management of these injuries. This problem is near totally preventable disease when necessary measures are provided. The children especially those less than five years old ie. infants and preschoolers are under higher risk of ingesting caustic substances if not enough attention is paid. These little children are not educated so cannot read the warnings on the "colorful", "bright" bottles which are very attractive for these curious, very mobile and explorative children. ${ }^{2}$

In U.S and Mexico, there are laws about warning labels, formulation and packaging of caustic substances in order to prevent ingestion of these substances. ${ }^{10}$ Similarly European Union Legislation aimed achieving a high level of protection of human health and the environment from chemicals by using similar rules. It has been shown that child-resistant safety caps, warning labels have significantly decreased caustic substance ingestion in developed countries. ${ }^{2,10}$ In Finland, for example, the production of some caustic substances which cause severe burn is forbidden. ${ }^{11}$

In this study group, some of the corrosive substances ingested by children were found to be bought from small markets or from the street vendors. ${ }^{12}$ These substances were usually kept in various bottles, cups or containers after bought from the vendors. Most common containers were coke bottles and water bottles. ${ }^{8}$ The importance of these unlabeled substances is that ingredients are unknown, their concentration is unknown 
and they are usually odorless or colorless without an original bottle. Lower socioeconomic groups prefer to buy these substances because of their low cost. The results show that these unlabeled substances have a tendency to cause more severe burns and among these caustic substances unlabeled degreasers, descalers and surface cleaners cause relatively more severe burns. Besides, these unlabeled substances are not recorded in Poison Information Centers. ${ }^{13}$

Another important point in these caustic substance ingested patients is the discontinuation of follow-up. In our study only $49 \%$ of the patients came to outpatient clinics with their results. Remaining patients discontinued their followup. The underlying cause of this discontinuation may be the judicial issues of ingestion of these substances. The lost of follow-up of the patients is a limitation of the study.

In order to reduce the prevalence of caustic substance ingestion, public education precedes every movement in this issue. There should be laws which prohibit the availability of unlabeled substances in the small markets and there has to be strict penalties for those who sell these substances. Governments should be encouraged to implement enough legislation about caustic products regarding their formulation, warning labels and packaging. ${ }^{10}$ The parents have to be educated to keep these caustic substances in their original child-proof bottles out of their reach. ${ }^{14}$ The parents should be educated about caustic substances, dangers of unlabeled ones and about first aid upon ingestion ie. they should know that they shouldn't feed the child or enforce vomiting. Educational programs should be prepared to be shown in the media and Ministry of Health should prepare public informative broadcasts about caustic substances. Informative leaflets about these substances and about their hazards should be distributed to children hospitals, therefore parents coming to these hospitals for any reason will be informed about caustic substances.

In Turkey, Ministry of Health published a notification about detergents and their active ingredients in December 2010. According to this notification, the caustic substances should have labels giving information about the ingredients and the percentage of active substances. This notification also emphasizes that packages of these substances shouldn't be similar to food and drink packages. Besides, this notification also includes prohibition about sale of caustics without original package and sale of unlabeled substances (Table 2).

A country wide meta-analysis should be carried out in order to constitute a common management protocol in the centers dealing with caustic substance ingestion.

\section{CONCLUSION}

Caustic substances are seriously dangerous to children especially who are three years old or less. According to this analysis, degreasers and descalers cause injuries more than other caustic substances and injury is even more severe following unlabeled degreasers and descalers. The trade of these unlabeled substances should be prevented by strict obligations and penalties. Furthermore, legal issues should be used for keeping these substances out of reach of children and having child protection lids.

\section{REFERENCES}

1. Kay M, Wyllie R. Caustic ingestions in children. Curr Opin Pediatr 2009;21(5):651-4.

2. McKenzie LB, Ahir N, Stolz U, Nelson NG. Household cleaning product-related injuries treated in US emergency departments in 1990-2006. Pediatrics 2010;126(3):509-16.

TABLE 2. Precautions to be taken in order to prevent caustic substance ingestion

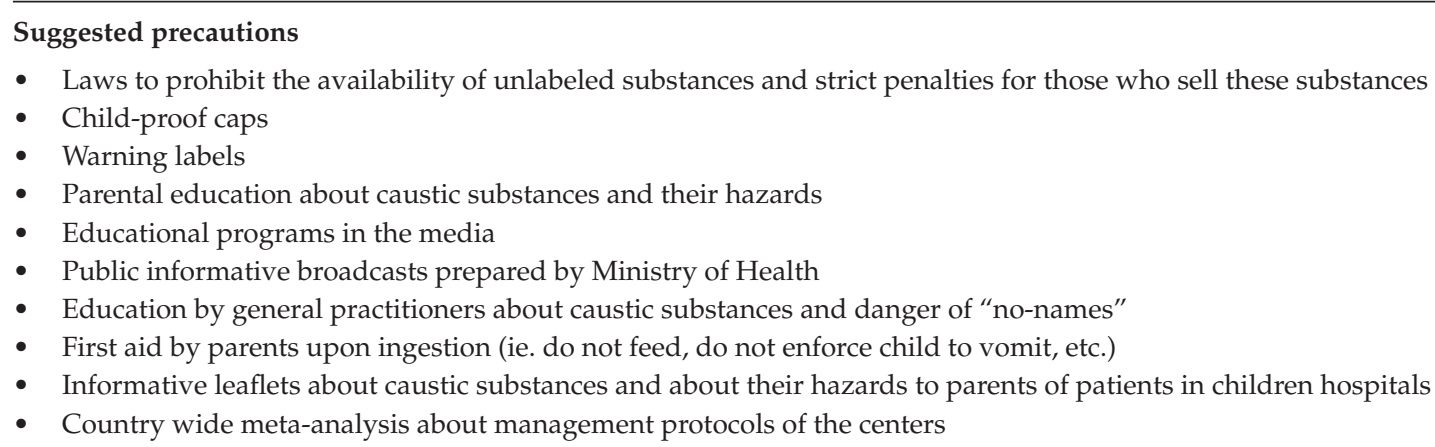


3. Ekpe EE, Ette V. Morbidity and mortality of caustic ingestion in rural children: experience in a new cardiothoracic surgery unit in Nigeria. ISRN Pediatr 2012;2012:210632.

4. Arıcı MA, Ozdemir D, Oray NC, Buyukdeligoz M, et al. Evaluation of caustics and household detergents exposures in an emergency service. Hum Exp Toxicol 2012;31(6):533-8.

5. Aktug T, Bingol-Kologlu M, Vargun R, Demirel- Yılmaz E, et al. Just a deception: TS 5682 approval for household chlorine bleaches manufactured in Turkey. $19^{\text {th }}$ Annual Meeting of the Turkish Association of Pediatric Surgeons with International Participation. 2001, 7-11 October. Antalya, Turkey.

6. Dial CL, Bambini DA.Caustic Esophageal Injury and Perforation. In: Arensman RM, Bambini DA, Almond PS, (eds). Vademecum Pediatric Surgery. Georgetown, Texas; 2000.Págs.383-5.

7. Çam H, Kıray E, Taştan Y, Cerci Ozkan H. İstanbul Üniversitesi Tıp Fakültesi Çocuk Sağlığı ve Hastalıkları Anabilim Dalı Acil Servisinde İzlenen Zehirlenme Olguları. Türk Pediatri Arşivi 2003;38(4):233-9.

8. Sarioglu-Buke A,Corduk N,AtesciF, Karabul M,etal.Adifferent aspect of corrosive ingestion in children: Socio-demographic characteristics and effect of family functioning. Int $J$ Pediatr Otorhinolaryngol. 2006;70(10):1791-8.

9. Temiz A, Oguzkurt P, Serin Ezer S, Ince E, et al. Predictability of outcome of caustic ingestion by esophagogastroduodenoscopy in children. World J Gastroenterol 2012;18(10):1098-103.

10. Sánchez-Ramírez CA, Larrosa- Haro A, Vásquez-Garibay EM, Macías-Rosales R. Socio-demographic factors associated with caustic substance ingestion in children and adolescents. Int $J$ Pediatr Otorhinolaryngol 2012;76(2):253-6.

11. Mamede RCM,de MelloFilhoFV.Treatment of caustic ingestion: an analysis of 239 cases. Dis Esophagus 2002;15(3):210-3.

12. Kayaalp L, Odabaşı G,Doğangün B,Cavusoglu P, et al. Corrosive esophagitis in children: social and psychological aspects. Türk Pediatri Arşivi 2006;41(1):24-30.

13. Boybeyi O, Göllü G, Kisa U, Bahadir B, et al. Danger in labeled bottles: analysis of corrosive substances. Turk J Gastroenterol 2015;26(1):71-72.

14. Contini S, Swarray-Deen A, Scarpignato C. Oesophageal corrosive injuries in children: a forgotten social and health challenge in developing countries. Bull World Health Organ 2009;87(12):950-4p 